\title{
ETIKA PELAYANAN PASTORAL BAGI KAUM MUDA DI TENGAH KEMAJEMUKAN DALAM GEREJA
}

\author{
Kasieli Zebua
}

\begin{abstract}
Pastoral service to young people is a noble ministry. This service is so special but challenging at the same time. It is special because this is a trust from God; it is full of challenges because young people are in a transitional period and also facing various crisis. It needs youth pastor who have good knowledge of the Word of God and cling to the truth. But on the other hand, pastoral ministry for young people is confronted with the plurality in the church. Pluralism is unavoidable but the church must take a good respond. Pluralism must be seen as a wealth and not as a competition arena. The spirit of service must be based on the love of Christ and not because of competition. Thus each church will provide the best pastoral service to young people. And in the end this pastoral ministry aims to produce young people who grow up in faith and action, as future generations who are loyal to the church and especially to God.
\end{abstract}

Key Words: Ethics, Service, Pastoral, Youth, Compound, Church

\begin{abstract}
Abstrak
Pelayanan pastoral kepada kaum muda merupakan pelayanan yang mulia. Pelayanan ini begitu istimewa dan sekaligus penuh tantangan. Istimewa karena pelayanan ini sebagai kepercayaan dari Allah; penuh tantangan karena kaum muda sedang berada pada masa transisi dan juga sedang menghadapi berbagai krisis zaman. Dibutuhkan gembala-gembala kaum muda yang memiliki pengetahuan yang baik akan Firman Tuhan dan berpegang teguh pada kebenaran. Namun di pihak lain, pelayanan pastoral kepada kaum muda diperhadapkan dengan kemajemukan dalam gereja. Kemajemukan ini tidak dapat dihindari tetapi gereja harus menyikapinya dengan baik. Kemajemukan harus dipandang sebagai kekayaan dan bukan sebagai ajang persaingan. Semangat pelayanan harus berdasarkan kasih Kristus dan bukan karena persaingan. Dengan demikian setiap gereja akan memberikan pelayanan pastoral yang sebaik-baiknya kepada kaum muda. Dan pada akhirnya pelayanan pastoral ini bertujuan untuk menghasilkan kaum muda yang bertumbuh dewasa dalam iman dan perbuatan, sebagai generasi-generasi penerus yang loyal kepada gereja dan terutama kepada Tuhan. Kata Kunci: Etika, Pelayanan, Pastoral, Kaum Muda, Majemuk, Gereja
\end{abstract}




\section{PENDAHULUAN}

Pelayanan pastoral merupakan pelayanan yang sentral di dalam pembinaan dan pendewasaan rohani jemaat. Pastoral berasal dari kata "pastor", dalam bahasa Ibrani רעה (ra'ah) ; Yunani пouńv (poimen) yang artinya gembala. ${ }^{1}$ Strong's Concordance mendefinisikannya a shepherd; hence met: of the feeder, protector, and ruler of a flock of men. ${ }^{2}$ Dari pengertian di atas dapat dipahami bahwa pelayanan pastoral kaum muda merupakan tugas seperti seorang gembala ${ }^{3}$ yang memelihara domba-domba, memberi makan, melindungi, merawat, dll.

Pelayanan pastoral seperti ini begitu penting. Fungsi seorang gembala dalam menggembalakan domba-domba sangat dibutuhkan, seperti yang disampaikan oleh Aart van Beek bahwa fungsi dari penggembalaan, yaitu: (1) membimbing (misalnya dalam konseling pra nikah), (2) mendamaikan/memperbaiki hubungan (misalnya konflik antar pribadi, masalah iman), (3) menopang/menyokong (dalam menolong mereka yang mengatasi krisis kehidupan), (4) menyembuhkan (orang yang terluka, yang berduka hatinya), dan (5) mengasuh (mendorong ke arah pengembangan, pertumbuhan secara holistik). ${ }^{4}$

Hal ini sejalan dengan apa yang disampaikan oleh Abineno bahwa manusia terdiri dari tubuh, roh dan jiwa yang menunjukkan manusia seutuhnya, yaitu manusia sebagai suatu totalitas. Oleh sebab itu pelayanan pastoral begitu penting bukan hanya karena manusia itu utuh, tetapi ia juga manusia yang hidup dalam konteks politik, sosial dan kebudayaan tertentu. Manusia itu memiliki relasi dengan sesamanya. Dan tidak hanya dengan sesamanya, ia juga terutama memiliki relasi dengan Allah, Penciptanya. ${ }^{5}$ Dengan demikian,

1 J.D. Douglas (Ed.), Ensiklopedi Alkitab Masa Kini - Jilid I A-L (Jakarta: Yayasan Komunikasi Bina Kasih/OMF, 2002), 330.

2 http://biblehub.com/greek/4166.htm diunduh tanggal 10 Oktober 2017.

3 Menurut penulis, istilah "gembala" sangat tepat bagi seorang yang melakukan pelayanan pastoral kepada kaum muda karena di dalamnya mencerminkan fungsi, tugas dan tanggung jawabnya. Jadi sebutannya "Gembala Kaum Muda" atau "Youth Pastor" lebih tepat dari pada sebutan "Pembina Kaum Muda", "Ketua Kaum Muda", "Pimpinan Kaum Muda" atau "Koordinator Kaum Muda" dan sebutan-sebutan lainnya.

4 Aart van Beek, Pendampingan Pastoral (Jakarta: BPK Gunung Mulia, 1999), 12.

5 J.L. Ch. Abineno, Pedoman Praktis untuk Pelayanan Pastoral (Jakarta: BPK Gunung Mulia, 2006), 48-49. 
pelayanan pastoral kepada kaum muda bersifat menyeluruh, jasmani dan rohani.

Sebutan pelayan, pimpinan, ketua, koordinator atau gembala kaum muda dalam tulisan ini memakai istilah Youth Pastor. Dengan demikian, ketika menyebutkan Youth Pastor telah mencakup seluruhnya dalam menjalankan tugas dan fungsi sebagai gembala bagi kaum muda.

\section{Keunikan Pelayanan Bagi Kaum Muda}

Urgensi dalam memahami keadaan kaum muda harus sejalan bahkan seimbang dengan urgensi pelayanan pastoral kepada mereka. Memahami keunikan kaum muda akan bermanfaat bagi pelayanan yang efektif dan produktif. Dengan kata lain, pelayanan akan stagnan ketika tidak memahami kehidupan kaum muda dalam keunikannya.

Gembala Agung, Tuhan Yesus Kristus telah memberi teladan bagaimana pengenalan kepada domba-domba sebagai hal yang sangat penting. Yesus berkata: Akulah gembala yang baik dan Aku mengenal domba-domba-Ku dan domba-domba-Ku mengenal Aku sama seperti Bapa mengenal Aku dan Aku mengenal Bapa, dan Aku memberikan nyawa-Ku bagi domba-domba-Ku (Yoh. 10:14-15).

Pengenalan terhadap kondisi kaum muda bukan hanya sangat penting tetapi mutlak dilakukan. Gembala kaum muda harus menyadari kebenaran ini. Harus peka terhadap kebutuhan-kebutuhan mereka. Tidak hanya kebutuhan-kebutuhan yang dirasakan tetapi juga kebutuhan-kebutuhan yang sesungguhnya di balik semua itu. Hal ini sejalan dengan apa yang disampaikan oleh Edmund Chan bahwa ada 3 aspek dalam peran penggembalaan seperti ini, yaitu (1) memperhatikan, yaitu membangun hidup orang yang dibimbing melalui perkataan, kehadiran dan kepedulian; (2) memberi konseling, yaitu mencari "akar" masalah dan bukan "ranting-ranting" yang kelihatan dari luar; dan (3) melatih, yaitu mengarahkan mereka dalam pertumbuhan rohani; memperlengkapi mereka dengan prinsip-prinsip (mengapa melakukan sesuatu) dan keterampilan (bagaimana melakukan dengan baik) yang dibutuhkan. ${ }^{6}$ Bagaimana 
peran ini dapat dilakukan dengan efektif dan efisien? Hanya bila mengenal kaum muda dengan baik.

Pengenalan ini harus dibangun melalui keterlibatan. Keterlibatan dengan kaum muda memberikan peluang besar bagi seorang gembala kaum muda untuk mengenal mereka lebih dekat. Mengenal kebutuhan dan tantangan-tantangan yang dihadapi sesuai dengan konteks mereka. Komunikasi dan interaksi yang baik mutlak dipelihara dalam keterlibatan ini. Dan pada akhirnya hasil dari keterlibatan ini ialah saling mengenal dan saling percaya. Yesus katakan, Aku mengenal domba-domba-Ku dan domba-domba-Ku mengenal Aku.

Oleh sebab itu, minimal ada dua hal besar yang perlu dipahami dari kehidupan kaum muda untuk dapat memberikan pelayanan pastoral kepada mereka yaitu (1) memahami bahwa mereka sedang memasuki fase trasisi, dan (2) memahami bahwa mereka sedang menghadapi krisis zaman. Kedua hal inilah yang membuat pelayanan pastoral kepada kaum muda menjadi sesuatu yang unik dan spesial.

\section{Melayani Mereka Yang Sedang Memasuki Fase Transisi}

Kaum muda ialah mereka yang berusia 16-30 tahun. ${ }^{7}$ Dalam usia ini mereka menghadapi transisi-transisi yang pada dasarnya merupakan sesuatu yang wajar. Transisi-transisi berupa transisi fisik, psikis, intelektual, sosial dan spiritual. Daryo mengutip tulisan dari seorang ahli psikolog bernama Santrock yang mengatakan bahwa orang dewasa muda termasuk masa transisi secara fisik (physically transition), transisi secara intelektual (cognitive trasition), serta transisi peran sosial (social role transition). ${ }^{8}$ Hampir sependapat dengan hal ini, Robby Chandra menyampaikan bawah kaum muda ada dalam

Church, 2008), 70.

7 Penetapan usia bagi pemuda ini sedikit beragam. Menurut Undang-Undang RI Nomor 40 tahun 2009 pasal 1 ayat 1, pemuda adalah warga negara Indonesia yang memasuki periode penting pertumbuhan dan perkembangan yang berusia 16-30 tahun; menurut UNESCO yang dapat disebut sebagai pemuda adalah mereka yang berusia antara 15-24 tahun; The African Youth Charter, pemuda adalah mereka yang berusia antara 15-35 tahun; sedangkan WHO menetapkan kelompok umur 18-65 tahun sebagai pemuda.

8 Agoes Daryo, Psikologi Perkembangan Dewasa Muda (Jakarta: Grasindo, 2004), 4. 
golongan yang sedang mengalami transisi fisik, psikis (kejiwaan), lingkup sosial dan spiritual. ${ }^{9}$

Dalam lingkup yang lebih luas, dalam era globalisasi di mana semua kemungkinan terbuka bagi kaum muda, transisi-transisi ini dipengaruhi oleh berbagai faktor, baik kemajuan ilmu pengetahuan dan teknologi sehingga terjadi berbagai pergeseran nilai, kultural, tindakan, dll. seperti yang disampaikan oleh Fahey dan Gale bahwa:

Pemuda dalam masa transisi digunakan untuk merujuk pada berbagai pergeseran: (1) Transisi dari satu sektor ke sektor lainnya misalnya dari sekolah ke tempat kerja, (2) Pergeseran antar generasi misalnya dari muda hingga dewasa dan (3) Pergeseran spasial misalnya migrasi dari lokasi pedesaan ke perkotaan. ${ }^{10}$

\section{Transisi Fisik (Physically Transition)}

Dari pertumbuhan fisik, kaum muda mengalami transisi dari masa remaja memasuki masa dewasa. Pada masa ini seorang kaum muda tidak lagi diperlakukan sebagai seorang anak atau remaja. Secara biologis, masa ini merupakan puncak pertumbuhan fisik yang prima, sehingga dipandang sebagai usia yang tersehat dari populasi manusia secara keseluruhan (healthiest people in population). Mereka memiliki daya tahan dan taraf kesehatan yang prima sehingga dalam melakukan berbagai kegiatan tampak inisiatif, kreatif, energik, cepat, dan proaktif. ${ }^{11}$ Dengan demikian, mereka senang dengan aktivitas dan kegiatan dan akan cepat jenuh dengan kegiatan yang monoton.

\section{Transisi Psikis (Psyche Transition)}

Secara psikologis, pada usia ini tidak sedikit di antara mereka yang kurang mampu mencapai kematangan. Hal ini disebabkan karena banyaknya masalah yang dihadapinya dan tidak mampu mengatasinya. Masalah-masalah itu di antaranya: (1) kesulitan mencari kerja; (2) susah mencari jodoh; (3) keinginan untuk menikah namun belum

9 Robby Chandra, Menatap Benturan Budaya (Jakarta: Binawarga, 1998), 100.

10 Stephanie Fahey and Fay Gale (ed.), Youth Trantition (Australia: AASSREC, 2005), 3.

11 Ni Made Sutriani, Karakteristik Perkembangan Masa Dewasa. Diunduh tanggal 17 Oktober 2017. Tersedia di https://mdsutriani.wordpress.com/2012/06/22 karakteristik-perkembangan-masa-dewasa/ 
mempunyai mata pecaharian; dan (4) kesulitan yang dialami setelah menikah, seperti: mengurus anak, memelihara keharmonisan keluarga, dan konflik dalam menggunakan penghasilan antara keperluan anak dengan biaya rumah tangga sehari-hari. Dalam menghadapi masalah tersebut mereka ragu-ragu untuk minta pertolongan dan nasihat orang lain karena enggan kalau-kalau dianggap "belum dewasa". ${ }^{12}$

\section{Transisi Intelektual (Cognitive Transition)}

Secara intelektual, pada masa ini mereka sedang berkembang dengan baik. Mereka mempelajari berbagai ilmu dan pengetahuan. Perkembangan ilmu dan teknologi sangat mendukung perkembangan intelektualnya. Mereka pintar dan selalu berpikir kritis, tetapi pada masa ini mereka belum banyak pengalaman. Maka tidak jarang mereka bingung dengan pengetahuan mereka, apalagi diperhadapkan dengan pengalaman orang tua. Dan kalau kondisi ini tidak segera diatasi, maka gap antar kaum muda dan orang tua kerap kali terjadi. Sehingga Paulus Tangdilitin mengatakan bahwa dibutuhkan kerendahan hati dan sikap terbuka, di mana orang tua mau belajar dunia anak muda, dan sebaliknya anak-anak muda mau mendengarkan orang tua yang punya segudang pengalaman. ${ }^{13}$

\section{Transisi Peran Sosial (Social Role Transition)}

Pada masa ini, kaum muda memasuki status sosial yang baru. Mereka sudah masuk dalam kelompok-kelompok sosial dalam masyarakat. Kelompok sosial yang baru ini merupakan tempat yang aman bagi kaum muda. Pengaruh kelompok ini bagi kehidupan mereka sangat kuat, bahkan seringkali melebihi pengaruh keluarga. ${ }^{14}$

Menurut Y. Singgih D. Gunarsa \& Singgih D. Gunarsa, kelompok sosial ini bersifat positif dalam hal memberikan kesempatan yang luas bagi kaum muda untuk melatih cara mereka bersikap, bertingkah laku dan melakukan hubungan sosial. Namun kelompok ini juga

12 Singgih D. Gunarsa, Psikologi Perkembangan (Jakarta: BPK Gunung Mulia, 2008), 103.

13 Paulus Tangdilitin, Sekilas Perkembangan Kajian Keluarga Perkotaan, dalam buku T.O. Ihromi (ed.), Bunga Rampai Sosiologi Keluarga (Jakarta: Yayasan Obor Indonesia, 2004), 6.

14 Agoes Daryo, Psikologi Perkembangan Dewasa Muda, 5. 
dapat bersifat negatif bila ikatan antar mereka menjadi sangat kuat sehingga kelakuan mereka menjadi "over acting" dan energi mereka disalurkan ke tujuan yang bersifat merusak. ${ }^{15}$ Artinya bahwa pada masa ini, mereka sudah mulai mengambil peran dan tanggung jawab di dalam kelompok sosial mereka sendiri.

\section{Transisi Rohani (Spiritual Transition)}

Secara spiritual kaum muda sedang memasuki pengalaman yang baru, mereka sudah mampu menghayati, merefleksi, bertindak dan menghubungkan diri pada realitas yang baru. ${ }^{16}$ Pada masa ini mereka sudah mandiri dan mulai menentukan pilihannya termasuk memilih kebutuhan rohaninya. Tidak jarang mereka mencari gereja yang cocok dan sesuai dengan kebutuhannya. Sesungguhnya mereka memiliki kehausan dalam hati dan jiwanya yang ingin dipuaskan.

\section{Melayani Mereka Yang Sedang Menghadapi Krisis Zaman}

Pelayanan kepada kaum muda tidak hanya seperti pelayan restoran yang menyediakan hidangan yang enak dan disukai oleh pengunjung. Pelayanan kepada kaum muda dibutuhkan suatu relasi dan pengenalan yang lebih baik. Kegagalan dalam melayani kaum muda seringkali disebabkan karena tidak memahami bahwa kaum muda sedang dalam masa krisis dan membutuhkan perhatian serta pengayoman. Terjadinya gap antara orang tua dan kaum muda salah satunya disebabkan karena hal ini. Dan kalau gereja juga tidak dapat memahami keadaan ini, maka kaum muda tidak dapat menemukan solusi terhadap krisis yang dihadapi sehingga seringkali mereka mencari jalan keluar di tempat yang salah.

Kehidupan manusia pada zaman ini semakin egois dan hanya mementingkan diri sendiri. Banyak orang mencintai diri sendiri dan sedikit orang yang sungguh-sungguh mengasihi Allah. Kondisi ini telah dinubuatkan oleh Rasul Paulus ketika ia mengingatkan dan menasihati seorang anak muda bernama Timotius, dalam suratnya ia berkata:

15 Singgih D. Gunarsa dan Y. Singgih D. Gunarsa, Psikologi Praktis: Anak, Remaja dan Keluarga (Jakarta: BPK Gunung Mulia, 2004), 116.

16 Shelton Charles, Spiritualitas Kaum Muda (Kanisius, 2003), 11. 
Ketahuilah bahwa pada hari-hari terakhir akan datang masa yang sukar. Manusia akan mencintai dirinya sendiri dan menjadi hamba uang. Mereka akan membual dan menyombongkan diri, mereka akan menjadi pemfitnah, mereka akan berontak terhadap orang tua dan tidak tahu berterima kasih, tidak mempedulikan agama, tidak tahu mengasihi, tidak mau berdamai, suka menjelekkan orang, tidak dapat mengekang diri, garang, tidak suka yang baik, suka mengkhianat, tidak berpikir panjang, berlagak tahu, lebih menuruti hawa nafsu dari pada menuruti Allah. Secara lahiriah mereka menjalankan ibadah mereka, tetapi pada hakekatnya mereka memungkiri kekuatannya. Jauhilah mereka itu! ${ }^{17}$

Kondisi seperti inilah yang sedang dihadapi oleh kaum muda saat ini, suatu masa yang sukar. Salah satu yang dihadapi adalah krisis identitas. Edmund Chan menanggapi krisis identitas ini, ia menyampaikan bahwa siapa diri kita sangat erat terkait dengan milik siapa kita ini. Makin kita mendekat kepada Allah, makin jelas jati diri kita di dalam Dia. Makin kita menjauh dari Allah, makin kita kehilangan identitas diri. ${ }^{18}$

Kaum muda sedang diperhadapkan kepada fenomena dan situasi dimana "hasil" dianggap sebagai kebenaran. Tidak penting bagaimana cara mencapai sesuatu, apakah benar atau salah, yang penting hasilnya menyenangkan dan menguntungkan. Maka Andik Wijaya menjelaskan situasi ini, ia berkata:

Medan perang orang muda zaman sekarang dibanjiri dengan banyak kesenangan dan kemudahan. Sebagian dari mereka tanpa sadar telah terperangkap di dalamnya, dan membentuk mereka menjadi fun-easy going generation. Gambaran umum menunjukkan bahwa mereka cenderung mengejar dan berorientasi pada kesenangan. Mereka adalah fun generation angkatan yang suka bersenang-senang. Mereka tidak mau menghadapi kesulitan, tidak suka dengan tantangan, tidak mau menerima tanggung jawab, cenderung memudahkan segala sesuatu. $^{19}$

Semua ini dampak dari krisis yang sedang melanda dunia. Beberapa krisis yang dihadapi kaum muda dalam zaman ini antara lain: (1) krisis identitas, (2) krisis kebenaran, (3) krisis otoritas, dan

172 Timotius 3:1-5.

18 Edmund Chan, Paradigma Mentoring, 143.

19 Andik Wijaya, Equipping Leaders to Fight for Sexual Holiness (Surabaya: Kenza Publising House, 2017), 122-123. 
(4) krisis spiritual. Seperti yang disampaikan oleh Edmund Chan bahwa kaum muda sedang menghadapi krisis identitas terjadi dalam zaman narsisme, krisis kebenaran dalam zaman pragmatisme, krisis otoritas dalam zaman konsumerisme, dan krisis spiritual dalam zaman kelelahan..$^{20}$ Lebih luas lagi, Alex Nanlohy mengatakan bahwa:

Kondisi zaman ini yang sarat dengan nilai-nilai materialisme, pragmatisme, hedonisme, konsumerisme dan lain sebagainya, menjadi tantangan besar bagi para remaja/kaum muda dalam menjalani tugas perkembangannya. Pengaruh dari media massa dan sumber-sumber informasi yang tidak tepat dan kurang mendidik telah "mengacaukan" proses pembentukan nilai-nilai hidup para remaja/kaum muda. Misalnya saja yang menjadi pandangan masyarakat saat ini tentang kesuksesan atau keberhasilan yang semata-mata hanya diukur dari materi yang dimiliki. ${ }^{21}$

Oleh sebab itu, memahami krisis zaman yang dihadapi kaum muda sangatlah penting. Pemahaman seperti ini akan menolong gereja dalam melakukan pelayanan pastoral yang tepat dan benar.

\section{PARADIGMA PELAYANAN PASTORAL}

Dalam pelayanan pastoral, Youth Pastor harus memahami dan memiliki paradigma yang jelas terhadap peyanan yang akan dikerjakan. Salah satu pengertian paradigma dalam Kamus Besar Bahasa Indonesia ialah kerangka berpikir. ${ }^{22}$ Dani Vardiansyah mendefinisikan paradigma dalam disiplin intelektual adalah cara pandang orang terhadap diri dan lingkungannya yang akan memengaruhinya dalam berpikir (kognitif), bersikap (afektif), dan bertingkah laku (psikomotorik). ${ }^{23}$ Dengan demikian, paradigma pelayanan pastoral yang dimaksud ialah cara pandang seorang Youth Pastor terhadap pelayanan pastoral akan memengaruhinya dalam berpikir, bersikap dan berperilaku dalam kapasitasnya sebagai pelayan kaum muda.

20 Edmund Chan, Paradigma Mentoring, 143-145.

21 Alex Nanlohy, Remaja di Tengah Krisis Zaman, diunduh tanggal 9 Oktober 2017; tersedia di http://www.perkantasjatim.org/index.php?g=articles\&id=76

22 https://kbbi.web.id/paradigma

23 Dani Vardiansyah, Filsafat IImu Komunikasi: Suatu Pengantar (Jakarta: Indeks, 2008), 27. 
Paradigma mendasar (paradigm base) di dalam pelayanan Pastoral Kaum Muda di antaranya ialah bahwa pelayanan itu harus bertujuan membawa jiwa-jiwa menjadi murid Kristus. Dan hal kedua ialah bahwa pemilik dari jiwa-jiwa tersebut adalah Kristus. Kedua paradigma ini akan mempengaruhi pikiran, sikap dan tindakan pelayanan terhadap kaum muda.

\section{Menjadikan Mereka Murid Kristus}

Matius 28:19-20, "Karena itu pergilah, jadikanlah semua bangsa murid-Ku dan baptislah mereka dalam nama Bapa dan Anak dan Roh Kudus, dan ajarlah mereka melakukan segala sesuatu yang telah Kuperintahkan kepadamu. Dan ketahuilah, Aku menyertai kamu senantiasa sampai kepada akhir zaman." Dalam struktur bahasa Yunani, ayat-ayat ini menunjukkan struktur kalimat bahwa "jadikanlah semua bangsa murid-Ku" sebagai subjek atau pokok utama yang menjadi tujuan dari Amanat Agung (Great Commis-

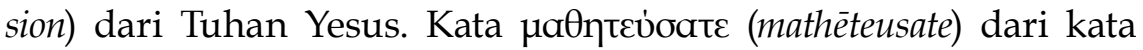

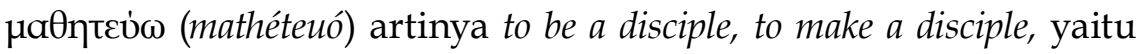
menjadikan seorang murid. ${ }^{24}$

Dengan demikian dapat dipahami bahwa segala aktivitas pelayanan yang diamanatkan oleh Tuhan Yesus harus dengan satu tujuan, yaitu menjadikan semua bangsa (nations) sebagai murid Kristus. Oleh sebab itu, kata kerja "pergilah", "baptislah", dan "ajarlah" merupakan aktivitas pelayanan sehingga melalui pelayanan itu dapat menghasilkan murid-murid bagi Kristus.

Paradigma ini harus menjadi fondasi yang kuat dalam pelayanan pastoral bagi kaum muda gereja. Sebab pelayanan tanpa fondasi ini akan mempengaruhi cara berpikir, sikap dan tindakan dalam melayani kaum muda. Setidaknya ada beberapa hal yang akan muncul bila paradigma ini tidak dimiliki, yaitu:

Pertama, aktivitas pelayanan menjadi tolok ukur kesuksesan pelayanan.

Berbagai program, aktivitas, kreativitas yang dibumbui dengan semangat entertainment menjadi fokus dalam pelayanan kaum muda yang hanya ahli dalam menyusun program, mempersiapkan

$24 \quad$ Alkitab Elektronik: Bibleworks 8.013z.1 
kegiatan (event), menyusun jadwal, melakukan aktivitas pelayanan dengan giat dan setia, tetapi mereka belum menjadi murid Kristus yang sejati. Seperti yang disampaikan oleh Edmund Chan bahwa:

Orang dapat memiliki rutinitas dan disiplin tanpa perjumpaan dengan Allah dan kekaguman akan Dia. Orang dapat membaca firman Allah tetapi kehilangan Allah yang berfirman. Orang dapat melayani Allah tanpa hati yang sungguh-sungguh mengasihi-Nya. Kehidupan dan pelayanan seorang Kristen dapat dengan mudah dipoles agar terlihat baik. Tetapi Allah memanggil kita untuk menjadi orang yang hidup dapat dipercaya, tidak berpura-pura. ${ }^{25}$

Hal senada disampaikan oleh Budi Abdiputra bahwa terlalu dangkal dan sempit kalau ukuran kesuksesan pelayanan kaum muda hanya berkutat pada hal-hal yang berbau aksesoris seperti ketersediaan fasilitas, gedung yang besar, uang yang banyak, kemampuan memanggil selebriti rohani, dan penciptaan program-program yang wah. ${ }^{26}$ Gereja hanya menghasilkan orang pintar bukan orang terdidik; hanya menghasilkan orang baik bukan seorang murid Kristus. ${ }^{27}$ Hal ini didukung oleh pendapat Mark Dever bahwa orang yang penuh aktivitas pelayanan belum tentu dewasa secara rohani..$^{28}$

Kedua, kuantitas menjadi tolok ukur kesuksesan pelayanan.

Salah satu indikator keberhasilan pelayanan ialah bertambahnya jiwa-jiwa yang masuk dalam gereja. Yesus katakan, jadikanlah semua bangsa murid-Ku. Yesus sedang berbicara mengenai kuantitas, yaitu semua bangsa, dan sekaligus kualitas, yaitu menjadi murid-Nya. Artinya bahwa tujuannya bukan hanya pada kuantitas, tetapi juga kualitasnya.

Ketika tujuan pelayanan hanya mengejar kuantitas, maka hal itu bisa saja tercapai. Segala upaya, daya, dana, dan berbagai kegiatan menarik untuk mengejar target jumlah anak-anak muda masuk gereja. Melalui pertanyaan-pertanyaan yang diajukan oleh Joel Comiskey ketika ia membahas mengenai masalah ini, dalam pertanyaan-pertanyaan tersebut mengandung peringatan-peringatan keras, ia bertanya:

25 Edmund Chan, Paradigma Mentoring, 60.

26 Budi Abdiputra, Generasi Pembaharu (Yogyakarta: ANDI, 2009), 25.

27 Joel Comiskey, Menuai Tanpa Batas (Jakarta: Metanoia, 2006), 75.

28 Mark Dever, 9 Tanda Gereja yang Sehat (Surabaya: Momentum, 2014), 275. 
Jika sebuah gereja menggunakan kehadiran Minggu paginya sebagai tanda keberhasilan utama mereka, apakah gereja tersebut memenuhi panggilan Yesus Kristus? Mungkinkah gereja yang menjadi model "keberhasilan pertumbuhan gereja" dihardik Tuhan, "Aku tahu segala pekerjaanmu: engkau dikatakan hidup, padahal engkau mati! (Why. 3:1)? Mungkinkah banyak gereja tidak tahu cara menyediakan komunitas Kristen bagi anggota-anggotanya? Mungkinkah ada kekurangan pengetahuan mengenai cara memim pin jemaat ke dalam persekutuan Kristen yang mendalam? ${ }^{29}$

Oleh sebab itu patut dipertimbangkan apa yang disampaikan oleh Edmund Chan bahwa:

Kita semua dipanggil oleh Allah untuk menjadi hebat tetapi tidak semua orang dipanggil oleh Allah untuk mengurusi pelayanan dalam skala yang besar. Yang pertama-tama harus diingat, tujuan kita bukanlah semata-mata bertumbuh secara kuantitas. Jika kuantitas menjadi ukuran, pelayanan Yeremia atau bahkan Tuhan Yesus sendiri bisa saja dianggap kurang berhasil. ${ }^{30}$

Dengan demikian, betapa pentingnya bagi Youth Pastor untuk memiliki paradigma pelayanan pastoral bahwa segala aktivitas pelayanan bertujuan untuk membawa kaum muda menjadi murid Kristus yang sejati. Pertumbuhan secara kuantitas tidaklah salah, tetapi pelayanan yang hanya berfokus pada kuantitas adalah salah. Sebab jika jumlah tidak sesuai target, maka ada kemungkinan jiwa-jiwa yang ada menjadi terlantar karena mereka bukanlah fokus pelayanan gereja. Dengan kata lain, kaum muda hanyalah sebagai alat bagi gereja untuk mengukur keberhasilan pelayanannya.

\section{Kristus sebagai Pemilik}

Paradigma kedua yang tidak kalah penting ialah menyadari bahwa kaum muda adalah milik Kristus. Rasul Paulus menyadari dan mengetahui kebenaran ini ketika ia menasihati jemaat Korintus melalui tulisannya: Tetapi kamu adalah milik Kristus dan Kristus adalah milik Allah (1Kor. 3:23), sebab ia yakin bahwa jemaat Korintus telah dibeli dengan harga yang lunas. Ia melanjutkan: Atau tidak ta- 
hukah kamu, bahwa tubuhmu adalah bait Roh Kudus yang diam di dalam kamu, Roh Kudus yang kamu peroleh dari Allah, -- dan bahwa kamu bukan milik kamu sendiri? Sebab kamu telah dibeli dan harganya telah lunas dibayar: Karena itu muliakanlah Allah dengan tubuhmu! (1Kor. 6:19-20; bnd. 1Kor. 7:23; 1Ptr. 1:18-19).

Kesadaran bahwa kaum muda adalah milik Kristus dan bukan milik gereja atau Youth Pastor akan memberikan pengaruh besar terhadap sikap dan tindakan pelayanan pastoral kepada mereka. Paradigma ini akan membuat pelayanan berbeda dan penuh semangat. Pelayanan akan semakin dinamis sebab yang dilayani adalah milik kepunyaan Kristus, pribadi-pribadi yang berharga dan bernilai bagi Kristus dimana Ia rela mati untuk mereka. Pelayanan akan lebih sungguh-sungguh dan penuh tanggung jawab sebab pertanggungjawaban langsung kepada Kristus sebagai pemilik.

Di sisi yang lain, kaum muda akan menyadari bahwa Kristuslah Pemilik mereka. Kristuslah yang patut disanjung, dipuja, ditinggikan dan "diidolakan". ${ }^{31}$ Jika tidak sampai kepada pemahaman seperti ini, maka apa yang terjadi dalam jemaat Korintus akan terus terulang, dan memang masih terjadi sampai saat ini. Favoritisme yang berlebihan kepada hamba Tuhan tidak menghasilkan kebaikan, sebaliknya terjadi kesombongan, perselisihan dan perpecahan (1Kor. 3:1-9; 4:6).

\section{ETIKA PELAYANAN PASTORAL DI TENGAH KEMAJEMUKAN DALAM GEREJA}

Alkitab mencatat bahwa gereja adalah tubuh Kristus. Gereja dipahami bukan sebagai gedung atau organisasi tetapi orangorang yang dipanggil Allah keluar dari kegelapan kepada terangNya yang ajaib. Sebagaimana pengertian gereja dari bahasa Yunani:

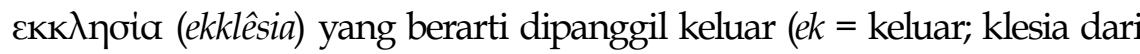
kata kaleo = memanggil) yang didefinisikan sebagai "perkumpulan" atau "orang-orang yang dipanggil keluar." 32 Lebih lanjut Jimmy

31 Mengidolakan seseorang seperti artis, aktor dll. merupakan hal yang sudah dianggap wajar pada zaman ini. Tetapi mengidolakan manusia siapapun melebihi kepada Kristus adalah salah, dan akibatnya ialah dosa (Yer. 17:5-8). 
Oentoro mendefinisikan gereja sebagai kumpulan orang-orang yang ada di dunia ini, yang dipisahkan Allah untuk menjadi alat-Nya, memberitakan kasih-Nya, dan yang membawa perubahan bagi dunia ini sebagai bagian dari rencana kekekalan-Nya. ${ }^{33}$

Sedangkan kemajemukan ${ }^{34}$ dalam gereja merupakan keanekaragaman yang ada dalam gereja secara universal namun satu kesatuan sebagai anggota tubuh Kristus. Keanekaragaman tersebut di antaranya berupa organisasi, ajaran/doktrin, liturgi, model pelayanan, dll. Tujuh gereja di Asia Kecil yang dicatat dalam Wahyu 2-3 memberikan gambaran kemajemukan gereja Tuhan, masing-masing memiliki kelebihan dan kekurangan, masing-masing memiliki pengalaman yang berbeda, lokasi yang berbeda, kultur yang berbeda, sosial dan ekonomi yang berbeda, dll.

Berdasarkan pengertian dan tujuan dari gereja dalam kemajemukannya di atas, penting bagi gereja lokal dalam hal ini Youth Pastor memiliki pemahaman yang benar dalam memandang kemajemukan gereja sehingga dapat menentukan sikap dan tindakan yang tepat dalam melayani kaum muda. Pertama, harus disadari bahwa dalam kemajemukannya, masing-masing gereja lokal tidak sama dalam banyak hal. Masing-masing memiliki konteks politik, sosial, budaya, ekonomi, pendidikan yang berbeda, yang dapat memengaruhinya dalam memahami firman Tuhan dan membangun ajaran/doktrin, bentuk/model liturgi dan pelayanan, dll. Masing-masing gereja lokal hidup dalam konteks yang berbeda yang harus dipandang sebagai kasih karunia Tuhan. Gereja Smirna tidak perlu pindah ke gereja Laodikia atau sebaliknya. Tuhan meminta masing-masing bertumbuh sesuai konteksnya.

Kedua, kemajemukan gereja harus dipandang sebagai suatu kekayaan dan bukan perbedaan. Youth Pastor memang harus memiliki prinsip kebenaran, tetapi bukan alasan menutup diri terhadap perbedaan. Sikap eksklusif justru membangun tembok yang tinggi serta menggali jurang yang lebar sebagai pembatas, pemisah dan

2017, tersedia di http://www.sabda.org/artikel/?q=book/export/html/20

33 Jimmy Oentoro, Gereja Impian - Menjadi Gereja yang Berpengaruh (Jakarta: Gramedia Pustaka Utama, 2010), xxxix.

34 Menurut KBBI, kata "majemuk" artinya terdiri dari beberapa bagian yang merupakan kesatuan; dan kata "kemajemukan" artinya keanekaragaman. 
penghalang dalam mengomunikasikan kebenaran dan akhirnya terjerumus dalam kebenaran diri sendiri. Faktanya, begitu banyak organisasi gereja, ajaran-ajaran/doktrin, liturgi, model pelayanan, dll. telah menjadi tembok pemisah antara satu dengan yang lain. ${ }^{35}$ Dengan demikian, beberapa hal berikut ini patut dipertimbangkan sebagai sikap etis dalam pelayanan pastoral kepada kaum muda di tengah kemajemukan gereja.

\section{Pemahaman tentang Keanggotaan Gereja}

Apakah artinya menjadi anggota suatu gereja? Apakah pentingnya bagi kaum muda terdaftar sebagai anggota gereja tertentu? Dua pertanyaan mendasar ini pada fakta empiris kurang diperhatikan oleh gereja-gereja dalam pelayanan pastoral kepada kaum muda. Juga buku-buku jarang menulis tentang hal ini. Baik buku-buku yang membahas penginjilan, penjangkauan jiwa atau pertumbuhan gereja jarang sekali menyentuh hal ini, tetapi salah satu yang memperhatikan tentang keanggotaan ini ialah Mark Dever di dalam bukunya yang berjudul "9 Tanda Gereja yang Sehat". Ia menjelaskan bahwa menjadi keanggotaan sebuah gereja adalah belajar lebih banyak tentang apa artinya menjadi seorang Kristen. Bagi mereka yang mengakui diri sebagai orang Kristen memiliki tanggung jawab dan kewajiban. Dan salah satu kewajibannya ialah menjadi anggota jemaat tertentu. ${ }^{36}$

Namun dalam hal ini, gereja memiliki keunikan tersendiri. Gereja cukup berbeda bila dibandingkan dengan menjadi anggota suatu perkumpulan, organisasi atau lembaga umum. Memang ada gereja-gereja tertentu yang begitu tertib dalam hal administrasi keanggotaan gereja, tetapi ada juga gereja-gereja yang tidak memberi perhatian khusus terhadap masalah ini. Gereja yang ketat akan mengatur hak dan kewajiban dari anggotanya, misalnya bagi

35 Adanya begitu banyak organisasi atau denominasi gereja saat ini salah satunya disebabkan oleh masalah-masalah perbedaan. Ada yang sifatnya prinsip, tetapi juga karena perbedaan lainnya. Sejak reformasi Marthin Luther yang menentang ajaran Katolik Roma pada tahun 1517, muncullah tokoh-tokoh Kristen yang kemudian masing-masing mendirikan persekutuan atau denominasi sendiri dengan membuat berbagai aturan gereja, ajaran dan keyakinan, tata liturgi gereja, metode dan cara pelayanan, dll. 
anggota jemaat akan mendapatkan pelayanan baptisan, pemberkatan nikah, dll. Keluar dari keanggotaan gereja secara otomatis hak-haknya akan dicabut. Tetapi bagi gereja yang perhatiannya lebih kepada melayani jiwa, sifatnya lebih terbuka dan fleksibel. Siapa saja yang masuk di dalam gerejanya dianggap sebagai anggota, tidak peduli dari mana mereka datang. Menanggap kondisi serupa, Richard Haverson dengan nada mengkritik berkata bahwa gereja sesungguhnya tidak lagi fokus pada jiwa-jiwa tetapi hanya memikirkan bagaimana gedung gerejanya besar dan dipenuhi oleh banyak orang setiap minggunya. ${ }^{37}$

Dua model keanggotaan gereja di atas memberikan pilihan bagi Youth Pastor dalam melaksanakan pelayanan pastoral kepada kaum muda. Setiap pilihan ada konsekuensi, tetapi dengan kepedulian dan pengertian yang bernar terhadap arti keanggotaan gereja secara komprehensif akan dapat menentukan sikap yang tepat dalam melaksanakan pelayanan pastoral kepada kaum muda.

\section{Pembinaan Rohani yang Ideal}

Michael Mack pernah menyampaikan bahwa Anda mungkin berhasil membina jemaat ketika mereka menyediakan waktu mendengar Anda berkhotbah satu jam setiap minggu, tetapi Anda kehilangan banyak waktu menyaksikan mereka bertumbuh dalam iman. ${ }^{38}$ Pernyataan ini menyiratkan keraguan terhadap pembinaan melalui khotbah satu jam dalam seminggu. Efektifkah pembinaan seperti itu? Mungkinkan terjadi pertumbuhan iman bagi jemaat yang hanya mendengar khotbah satu jam dalam seminggu. Tentu saja jawaban terhadap setiap pertanyaan ini bersifat relatif, bisa ya dan bisa tidak. Maka betapa pentingnya pembinaan sebagaimana telah dibahas di atas bahwa seorang Youth Pastor memiliki tugas dan fungsinya dalam menggembalakan kaum muda.

Tugas dan fungsi Youth Pastor dalam pelayanan ini cukup kompleks, tidak hanya menyampaikan khotbah, tetapi juga komunikasi dan keterlibatan untuk menolong kaum muda bertumbuh dalam membangun relasi dengan Tuhan, membangun keakraban

37 Richard Halverson, How I Change My Think About the Church (Grand Rapids: Zondervan, 2000), 97.

38 Michael Mack, The Synergy Church (Grand Rapids: Baker Books, 1996), 55. 
dengan sesama sebagai anggota tubuh Kristus, serta menolong mereka menjawab kebutuhannya dalam menghadapi tantangan sesuai dengan kebenaran firman Tuhan. Bagaimana hal ini dilakukan? Harus tertanam di dalam gereja lokal. Mark Dever berkata,

Dengan menjadi seorang anggota gereja, kita sedang bergandengan tangan satu dengan yang lain untuk mengenal dan dikenal oleh satu sama lain. Kita sepakat untuk menolong dan menguatkan satu sama lain ketika kita perlu diingatkan tentang pekerjaan Allah dalam hidup kita atau ketika kita perlu ditantang tentang ketimpangan antara perkataan dan perbuatan kita. ${ }^{39}$

Pentingnya pembinaan ini harus menjadi pertimbangan bagi Youth Pastor. Kaum muda harus diajar untuk memilih digembalakan di satu gereja tertentu. ${ }^{40}$ Dan Youth Pastor juga harus berani melepas kaum muda bila mereka lebih memilih di gereja lain demi terciptanya pembinaan dan tercapainya kedewasaan rohani mereka. Tetapi di sisi yang lain, Youth Pastor harus membenahi dirinya dan memberikan pelayanan yang dapat menjawab kebutuhan kaum muda sesuai tujuan dan kebenaran firman Tuhan.

Di tengah kemajemukan gereja, bisa saja terjadi bahwa ada yang melayani dengan motivasi yang salah. Mungkin ada target-target tertentu, misalnya jumlah harus sekian dalam satu tahun, atau hal lainnya sehingga segala cara dilakukan untuk menarik banyak kaum muda masuk dalam gereja/persekutuan kaum muda. Dan ironisnya kaum muda yang ditarik ialah mereka yang berasal dari gereja lokal tertentu, sehingga ada kesan terjadinya persaingan di antara gereja. Namun demikian perlu dipertimbangkan apa yang disampaikan oleh Ciptawilangga \& Heryanto ketika membahas mengenai hal ini, mereka menyampaikan bahwa:

Persaingan antar gereja tidak selalu berkonotasi negatif. Dalam dunia ekonomi, pemerintah sering membiarkan terjadinya persaingan yang sehat karena dengan adanya persaingan itu diharapkan terjadi

39 Mark Dever, 9 Tanda Gereja yang Sehat, 195.

40 Beberapa saran penting dari banyak saran lainnya sebagai bahan pertimbangan ketika memilih suatu gereja, antara lain saran dari Alki F. Tombuku, Enam Kriteria Gereja yang Alkitabiah. Diunduh tanggal 22 Oktober 2017, tersedia di www.kristenalkitabiah. com/enam-kriteria-gereja-yang-alkitabiah/ 
suatu peningkatan mutu pelayanan atau produk yang akhirnya dapat dinikmati oleh konsumen. Persaingan justru dapat meningkatkan mutu institusi. Dalam konteks kehidupan gerejawi, persaingan terutama terjadi dalam usaha pengembangan gereja. Gereja-gereja berusaha mengembangkan dirinya dengan menawarkan berbagai variasi dalam ibadah, mendatangkan pengkhotbah atau pembicara terkenal, mengikutsertakan jemaat sebanyak mungkin dalam pelayanan mereka, dan membuka berbagai pelayanan yang diharapkan dapat memenuhi kebutuhan rohani jemaat, seperti konseling pribadi, dan banyak kegiatan lainnya. ${ }^{41}$

Artinya bahwa melakukan pelayanan yang sebaik-baiknya, dan digerakkan oleh motivasi yang benar dan tulus adalah ciri dari gereja yang sehat. Tetapi usaha-usaha dalam mengembangkan pelayanan gereja seperti yang disampaikan di atas perlu ditinjau lebih lanjut.

\section{Memahami arti pentingnya Organisasi}

Gereja sebagai organisasi memiliki peran penting di dalam mengelola berbagai kegiatan dan aktivitas pelayanan, termasuk keanggotaan gereja. Sekalipun gereja sebagai sebagai tubuh Kristus, gereja yang Am, tetapi sebagai organisasi/denominasi masing-masing memiliki peran dan tanggung jawab yang harus dihormati oleh organisasi/denominasi lainnya. Maka terkait dengan perpindahan anggota gereja, Gaylord Noyce menyampaikan bahwa:

Pada saat seseorang ingin pindah dari satu jemaat ke jemaat lain yang berlainan latar belakang tradisinya, pemberitahuannya melalui permohonan adanya surat dari jemaat baru merupakan tindakan tepat, bahkan bila perubahan itu terjadi dari Katolik ke Protestan. Jelaslah, tanggapannya tidak selalu rutin seperti halnya bila berasal dari jemaat-jemaat di dalam denominasi yang sama. Bila dalam beberapa kasus hal itu tak bisa diwujudkan, toh gerak-isyarat semangat oikumenis sedemikian layak ditempuh. ${ }^{42}$

Tidak adanya aturan tentang perpindahan jemaat antar gereja di satu sisi mengindikasikan bahwa gereja sebenarnya harus menjadi

41 Yunus Ciptawilangga \& Matius Heryanto, Menang Dalam Persaingan Gereja (Jakarta: Metanoia, 2003), 3-4.

42 Gaylord Noyce, Tanggung Jawab Etis Pelayanan Jemaat - Etika Pastoral (Jakarta: BPK Gunung Mulia, 2011), 128. 
gereja yang am (universal), yang tidak berorientasi pada kepentingan denominasi belaka, tetapi melihat dengan perspektif yang lebih luas, yaitu gereja sebagai Tubuh Kristus yang utuh. Tetapi, sebagai gereja yang baik, tentunya gereja perlu melayani jemaatnya dengan baik dan untuk itulah dibutuhkan kiat-kiat tertentu untuk mempertahankan jemaatnya. Semakin berhasil sebuah gereja lokal memperkecil perpindahan jemaatnya, semakin tinggi kualitas gereja itu dalam melayani para jemaatnya. ${ }^{43}$

Tetapi dari sisi yang lain, mudahnya perpindahan jemaat antar gereja disebabkan karena tidak mempunyai sistem keanggotaan gereja yang mengikat. Gereja tidak dapat memaksakan jemaat untuk tetap beribadah di gereja semula karena tidak ada keterikatan hukum. Bahkan, jemaat yang dibaptis di suatu gereja tidak wajib beribadah di gereja tersebut. Dalam Alkitab sekalipun tidak ada bagian yang mengatur bagaimana seharusnya perpindahan anggota antar gereja dilakukan.

Oleh sebab itu, penting memahami arti keberadaan sebuah organisasi gereja sehingga kalaupun terjadi perpindahan, harus jelas dan bukan karena suatu persaingan yang tidak sehat. Sebab persaingan yang tidak sehat menimbulkan kerugian seperti yang disampaikan oleh Ciptawilangga \& Heryanto bahwa:

Persaingan ini menimbulkan kegamangan bahwa ada gereja yang jemaatnya semakin hari semakin berkurang, tetapi ada pula yang semakin bertambah. Selain karena perpindahan tempat tinggal, penyusutan jemaat di sebuah gereja bisa disebabkan oleh beberapa hal: Pertama, karena domba hilang. Gereja dengan jemaatnya yang jumlahnya semakin berkurang dapat diibaratkan dengan kawanan domba yang hilang. Domba itu tersesat karena ia tidak lagi mau beribadah di gereja semula. Secara langsung atau perlahan-lahan mereka tidak lagi mau beribadah ke gereja semula. Kedua, karena domba itu "dicuri". Artinya, jemaat yang dahulu beribadah di sebuah gereja, sekarang beribadah di gereja lain. ${ }^{44}$

Dengan demikian, pelayanan kepada kaum muda tidak lepas dari peran dan tanggung jawab gereja sebagai organisasi/denominasi. Setiap gereja wajib saling menghargai untuk kemajuan dan per-

43 Yunus Ciptawilangga \& Matius Heryanto, Menang Dalam Persaingan Gereja (Jakarta: Metanoia, 2003), 8.

44 Ibid, 4. 
tumbuhan bersama di dalam Kristus.

\section{TANTANGAN PELAYANAN PASTORAL DI TENGAH KE- MAJEMUKAN DALAM GEREJA}

Mencermati transisi-transisi yang dihadapi kaum muda dan bagaimana etika pelayanan pastoral di tengah kemajemukan gereja saat ini, maka pelayanan pastoral kepada kaum muda tidaklah gampang. Gereja harus mengantisipasi dan menyikapi tantangan yang menantang ini dengan bijak. Gereja tidak cukup puas dengan jumlah kaum muda yang banyak, tetapi juga harus melayani mereka dengan benar dan tepat. Sebab tantangan dalam pelayanan gereja semakin besar, baik tantangan secara intern maupun ekstern. Menanggapi keadaan seperti ini, Ciptawilangga \& Heryanto mengatakan bahwa:

Bila kita memandang keadaan gereja dewasa ini, kita melihat bahwa ternyata gereja mendapat serangan dan saingan, baik dari luar maupundari dalam. Dariluar, kita melihat kebohonganajaran humanisme, ajaran sesat, sistem kepercayaan yang salah, dan janji bahwa hidup manusia itu akan lebih bermakna apabila manusia menjalani hidupnya dengan cara memuaskan hawa nafsu seperti yang dinyatakan Paulus dalam Filipi 3:19, "Kesudahan mereka ialah kebinasaan, Tuhan mereka ialah perut mereka, kemuliaan mereka ialah aib mereka, pikiran merekasemata-mata tertuju kepada perkara duniawi." Dipihaklain, dalam era globalisasi ini, di mana segala bentuk kehidupan menjadi begitu ketat dan dinamis, mau tidak mau gereja ikut terseret dalam dunia persaingan. Persaingan yang terjadi bukan hanya sesama gereja, tetapi juga dengan agama lain, sekularisme, dan teknologi. ${ }^{45}$

Tantangan-tantangan ini harus dihadapi secara positif. Sekalipun faktanya timbul fenomena antara lain terjadinya persaingan di kalangan gereja. Misalnya, bersaing merebut perhatian dari jemaat (kaum muda) dengan berbagai kegiatan-kegiatan yang menyenangkan, tetapi fenomena ini harus dilihat secara positif dan dengan perspektif firman Tuhan. Memang dampak langsung dari fenomena ini ialah dengan mudahnya kaum muda pindah-pindah gereja sesuai dengan selera dan keinginannya. Sehubungan dengan hal itu, Tim Wright mengungkapkan bahwa, "Sekarang ini orang (kaum muda) memilih gereja sama seperti memilih segala sesuatu yang lain sebagai

45 Yunus Ciptawilangga \& Matius Heryanto, Menang Dalam Persaingan Gereja, 3. 
konsumen. Mereka bergerak ke mana ada aksi, di mana mereka berpikir kebutuhannya akan terpenuhi tanpa mempedulikan apapun, doktrin, atau pun lokasi." ${ }^{\prime 46}$

Bila keadaan ini tidak disikapi dengan tepat dan benar, maka beberapa problem berikut akan melanda kaum muda dan gereja, antara lain terjadinya degradasi kedewasaan rohani, lunturnya nilai loyalitas. Dan bila kedua hal ini terjadi, maka problem berikutnya ialah gereja akan kehilangan generasi penerus.

\section{Degradasi Kedewasaan}

Di dalam konteks kekristenan pertumbuhan rohani merupakan sesuatu yang bersifat mutlak. Pertumbuhan kerohanian merupakan suatu keharusan, bukan pilihan. Setiap pribadi yang menyatakan diri sebagai orang Kristen harus tahu bahwa Tuhan mengharapkannya bertumbuh hingga mencapai kedewasaan.

Kerohanian harus bersifat dinamis. Kalau terjadi stagnasi maka segera melakukan evaluasi. Seperti yang disampaikan oleh Robinson, bahwa kerohanian di dalam konteks kekristenan harus bertumbuh secara progresif, dari hari ke sehari, dari waktu ke waktu. ${ }^{47}$ Itulah sebabnya pertumbuhan rohani di dalam kekristenan merupakan hal yang sangat penting. Perry G. Downs memberikan penjelasan dalam tulisannya yang berjudul Pembentukan Iman: Mengantar Kaum Muda kepada Kedewasaan Rohani bahwa:

Kedewasaan rohani adalah tujuan terakhir dari pelayanan. Sasaran dari pelayanan kaum muda di dalam gereja adalah penjangkauan dan pendewasaan. Pelayanan kaum muda yang efektif harus senantiasa melibatkan beban penginjilan, namun juga perlu berfokus untuk membangun iman kaum muda. Hasil akhir dari jerih payah kita adalah kedewasaan rohani para kaum muda. ${ }^{48}$

Tetapi bagaimana kaum muda dapat bertumbuh dan mencapai kedewasaan rohani apabila mereka tidak tergembala dengan baik? Memang benar, secara psikologis kaum muda masih labil dan sedang

46 Selvester M. Tacoy, 6 Kunci Sukses Pelayanan Kaum Muda, 45.

47 Darrell W. Robinson, Total Church Life (Bandung: Lembaga Literatur Baptis, 2004), 91.

48 Perry G. Downs, Pembentukan Iman: Mengantar Kaum Muda kepada Kedewasaan Rohani, dalam Warren S. Benson \& Mark H. Center III (ed.), Pedoman Lengkap untuk Pelayanan Kaum Muda, (Bandung: Kalam Hidup, 1999), 55. 
mencari jati dirinya. Tetapi harus dipertimbangkan kebenaran ilustrasi yang disampaikan oleh Eva Yunita bahwa jemaat yang suka pindah-pindah gereja seperti benih yang ditanam kemudian dipindahkan, ditanam dan dipindahkan lagi, lama kelamaan ia akan mati. ${ }^{49}$

\section{Lunturnya Nilai Loyalitas}

Alkitab mengajarkan banyak hal tentang kesetiaan. Melalui perumpamaan tentang talenta dalam Matius 25:14-30; bnd. Lukas 19:12-27, Yesus mengajarkan bagaimana setia dalam hal yang kecil. Kepada jemaat di Smirna, Yesus menasihati mereka untuk tetap setia sampai mati (Why.2:10). Kesetiaan merupakan bukti dari iman dan ketaatan kepada Tuhan. Dibutuhkan kematangan dan kedewasaan rohani supaya kaum muda memiliki loyalitas kepada Tuhan, kepada gereja dan pelayanan. Jemaat yang tidak dewasa tidak akan kuat dalam menghadapi ujian kesetiaan. Sehingga Budi Abdipatra berkata bahwa generasi sekarang ini mudah menyerah dan pasrah pada tantangan sebab mereka adalah produk instan. ${ }^{50}$ Artinya bahwa kaum muda yang hanya mengikuti kesenangan hatinya kemudian ditopang dan dimanjakan oleh gereja melalui kegiatan atau aktivitas pelayanan, tidak akan kuat ketika menghadapi tantangan dan ujian iman.

\section{Kehilangan Generasi Penerus}

Apabila kaum muda gereja dibentuk dengan motivasi hanya sebagai prestise pelayanan gereja dan bukan untuk kepentingan kaum muda itu sendiri, maka hasilnya adalah kaum muda tidak dewasa dalam rohani, lemah dan mudah menyerah ketika menghadapi tantangan iman, dan akhirnya gereja kehilangan generasi penerus, sekalipun mereka tetap ada di dalam gereja. Maka mencermati kondisi demikian, Leroy Lawson berkata bahwa kehilangan generasi muda tidak semata-mata mereka pindah agama atau meninggalkan Tuhan, tetapi gereja kehilangan generasi yang meneruskan visi Tuhan di dunia. ${ }^{51}$

49 Eva Yunita, Pemimpin Muda Peka Zaman (Yogyakarta: Andi, 2009), 67.

50 Budi Abdipatra, Generasi Pembaharu, 97.

51 Leroy Lawson, Gereja Perjanjian Baru - Dahulu \& Sekarang (Surabaya: Yakin, 2008), 75. 


\section{KESIMPULAN}

Betapa pentingnya pelayanan kepada kaum muda. Suatu pelayanan yang istimewa, yang membutuhkan kasih dan perhatian ekstra, dana dan daya, serta komitmen dan kesungguhan. Sebab pelayanan ini ditandani dengan banyak tantangan, rintangan dan godaan. Dibutuhkan pribadi-pribadi yang berhati gembala, yang berjiwa misi dan berkararter Kristus. Kaum muda membutuhkan orang yang dapat memahami dan mengerti keadaan mereka, sekaligus dapat menuntun mereka keluar dari berbagai transisi dan krisis yang sedang mereka hadapi.

Di tengah kemajemukan gereja yang dipacu oleh kemajuan zaman, kaum muda membutuhkan tongkat gembala yang dapat mengarahkan, mengajar dan mendidik mereka untuk menemukan air yang tenang dan rumput yang hijau. Mereka membutuhkan pengajaran Firman kebenaran, dan membutuhkan tuntunan melalui kuasa Roh Kudus untuk mengimplementasikan kebenaran dalam kehidupan sehari-hari. Oleh sebab itu, gereja harus terus berinovasi sesuai prinsip-prinsip kebenaran Firman dalam menghadapi berbagai pelayanan kaum muda yang cukup kompleks sesuai konteks kaum muda saat ini. 